University of Minnesota Morris Digital Well

University of Minnesota Morris Digital Well

$4-2018$

\title{
The Art of "Reading-To" and the Post-Holocaust Suicide in Schlink's The Reader
}

\author{
Michael Lackey \\ University of Minnesota Morris, lacke010@morris.umn.edu
}

Follow this and additional works at: https://digitalcommons.morris.umn.edu/eng_facpubs

Part of the German Literature Commons

\section{Recommended Citation}

Lackey, Michael. 2018. "The Art of 'Reading-To' and the Post-Holocaust Suicide in Schlink's The Reader." Philosophy and Literature 42.1:145-164.

This Article is brought to you for free and open access by the Faculty and Staff Scholarship at University of Minnesota Morris Digital Well. It has been accepted for inclusion in English Publications by an authorized administrator of University of Minnesota Morris Digital Well. For more information, please contact skulann@morris.umn.edu. 


\title{
The Art of "Reading-To" and the Post-Holocaust Suicide in Schlink's The Reader
}

\author{
Michael Lackey
}

This is an Accepted Manuscript of an article published by John Hopkins University Press in Philosophy and Literature in April 2018, available online: https://muse.jhu.edu/article/695386

The post-Holocaust suicide of a concentration camp survivor is particularly unsettling. One thinks, for instance, of Cliff Stern's devastated response to Professor Louis Levy's death in Woody Allen's movie Crimes and Misdemeanors. Loosely based on Primo Levi, Allen's professor provides in short documentary clips an astute analysis of the contradictions of a loving God in the Old Testament and stoically counsels embracing life despite the indifference and occasional cruelty of the universe. Having experienced, understood, and accepted the absurdity and injustice of life, Levy, one might think, would rage to the bitter end against the dying of the light. But for no apparent reason, he kills himself. Cliff's response is telling. After noting that the philosopher's entire family had been killed during the Holocaust, Cliff says that Levy "had seen the worst side of life, and he was always affirmative, always said yes to life, yes, yes, and now today he says no." ${ }^{1}$ Killing oneself during the worst time imaginable might seem to be the logical response. Thus, what makes the survivor's post-Holocaust suicide so difficult to register is the fact that the person overcame the worst, so - seemingly — he or she should be able to look forward to better days. Bernhard Schlink's The Reader is a scandalous text for many reasons, as William Collins Donahue and Cynthia Ozick have argued, but as I intend to demonstrate, scholars have still not confronted the work's most shocking suggestion, which is that the postHolocaust suicide of Nazi perpetrator Hanna Schmitz should be read alongside the voluntary death of Holocaust survivor Jean Améry. ${ }^{2}$

Sally Johnson and Frank Finlay have rightly noted that it is difficult to understand "the motivation for Hanna's suicide." Jeremiah P. Conway claims that Hanna commits the act because, in becoming literate, she is overwhelmed with "guilt and anguish" and thus "she takes her life as a way of fulfilling an obligation to the dead." "Bill Niven, instead of offering a single answer to this enigma, speculates about a wide range of possibilities, including "fear of release from the security of prison, a sense that her relationship with Michael can never be as it was, and, perhaps more pertinently, a general dread of the outside world. Her suicide is also intended in part as a gesture of penance." Many potential motivations are at work here, but I contend that not one of them gets to the most decisive reason why Hanna takes her life.

Important clues to the motivation come shortly after Michael discovers that Hanna killed herself. While in her cell, Michael notices works on Hanna's bookshelf from "Primo Levi, Elie Wiesel, Tadeusz Borowski, Jean Améry - the literature of the victims, next to the autobiography of Rudolf Hess, Hannah Arendt's report on Eichmann in Jerusalem, and scholarly literature on the camps." ${ }^{\prime 6}$ The specificity in this passage is too conspicuous to ignore. In the following pages, I will use works from these six writers in order to offer an interpretation for Hanna's suicide. 
My primary claim is that something in the nature of Michael's behavior leads Hanna to kill herself, and to understand that something, it is crucial to know Hannah Arendt's controversial book Eichmann in Jerusalem. One of Arendt's central objectives is to explain how someone could willingly play a major role in the extermination of millions of people. She found some answers in the person of Adolf Eichmann. A master of bureaucratic efficiency, Eichmann was not unintelligent. The man had a natural gift for organizing administrative processes and departments. For instance, when he started working in Vienna as the head of the Center for Emigration of Austrian Jews (also called the Central Office for Jewish Emigration), Eichmann realized that the department was totally dysfunctional, complete with endless delays, unprocessed requests, and rampant corruption. Given his assembly-line approach to the world, he set up an efficient system that would make it possible to process emigration requests within hours rather than weeks.

The results were so staggering that Jewish leaders were both amazed and horrified by his model. As these leaders state:

This is like an automatic factory, like a flour mill connected with some bakery. At one end you put in a Jew who still has some property, a factory, or a shop, or a bank account, and he goes through the building from counter to counter, from office to office, and comes out at the other end without any money, without any rights, with only a passport on which it says: "You must leave the country within a fortnight. Otherwise you will go to a concentration camp."7

Essentially, the results were the same as in the old model, but at least that model maintained the illusion that one's humanity was potentially acknowledged. With Eichmann's new, bureaucratically efficient version, all pretense of the Jews' dignity was jettisoned as the systematic divestiture of the Jews' rights was put on display, as if one were witnessing the production process in a high-tech factory.

What was it about Eichmann that enabled him to execute his bureaucratic duty with enthusiasm but to overlook the horrified response to his work? This is the question that Arendt seeks to answer in her book about Eichmann, and the end result is her theory about the banality of evil. Central to this theory is the failure to think, which is, according to Arendt, Eichmann's greatest failing as a human being. To illustrate, Arendt examines the way Eichmann uses language. Striking for her is the fact that, instead of producing anything resembling a unique or insightful thought about his experience or philosophy as a prominent Nazi, Eichmann uttered nothing but mindless platitudes. As Arendt claims, "officialese became his language because he was genuinely incapable of uttering a single sentence that was not a cliché" (EJ, pp. 46, 48). Based on her many hours of listening to him in court and on tape, Arendt concludes: "The longer one listened to him, the more obvious it became that his inability to speak was closely connected with an inability to think, to think from the standpoint of someone else" (p. 49). According to Arendt's logic, if Eichmann could think, he would have been able to say something more than just a cliché and he would have been able to think from the standpoint of someone else, thus precluding him from behaving as he did. But because he could not think, he could do neither of these, which explains why he was capable of committing atrocities against Jews with emotional and psychological impunity. 
Given the direct reference to Arendt's book about Eichmann, it might seem that Schlink subscribes to Arendt's theory about thinking. But Schlink goes out of his way throughout the novel to expose the limitations of Arendt's thinking-based model for explaining Eichmannlike behavior. Michael makes this point directly when reflecting on his decision to visit Hanna as a fifteen-year-old. Why did he go to her? He answers: "I can recognize that events back then were part of a lifelong pattern in which thinking and doing have either come together or failed to come together-I think, I reach a conclusion, I turn the conclusion into a decision, and then I discover that acting on the decision is something else entirely, and that doing so may proceed from the decision, but then again it may not. Often enough in my life I have done things I had not decided to do" (R, p. 20). Thinking, Michael understands, can play a role in determining human action. But many times, a person does the exact opposite of what thinking proposes. For this reason Michael concludes that something more or other than thinking governs behavior: "Somethingwhatever that may be-goes into action" (p. 20). Based on the logic of Michael's model, it would be possible for someone like Eichmann to think but still do the exact opposite of what thinking dictates.

To underscore not just the limits of thinking but also the dangers of overemphasizing its importance, Schlink has Michael briefly describe thinking's disastrous consequences on his family life. Michael's father is "a professor of philosophy, and thinking was his life" ( $R$, p. 30). At first blush, it might seem that having as a father a philosophy professor who is committed to thinking would be a desirable state of familial affairs. But in the very next sentence, Michael describes his father's relationship to the family: "Sometimes I had the feeling that all of us in his family were like pets to him" (p. 30). Narratively a link exists between the philosopher's commitment to thinking and his dysfunctional interactions with his family. To put the matter simply, philosophical thinking is not something that necessarily leads to a healthy or desirable living situation, not something that enables a person to see from the perspective of the other. To the contrary, it can and in fact sometimes does cultivate indifference or even alienation. Thus, thinking is not that which would prevent someone from violating or murdering a whole race of people. Indeed, it might even be something that could contribute to such an atrocity.

If Schlink is suggesting that thinking fails to lead to productive action and fruitful interactions among people, or that thinking can be destructive, then what is that "something" that could prevent the mundane murder of millions or promote more positive behavior? Ironically, it is through Hanna that Schlink gives readers an alternative. At this point, I want to take issue with Niven's approach to the novel. Niven notes that the liberal humanist tradition holds that reading the canon would make people moral citizens, but he suggests that Schlink debunks this view, because even though Michael reads works from the canon to Hanna, she still behaves badly. By the end of the novel, Hanna undergoes a transformation, and what leads to her "moral development," Niven claims, is Hanna's reading of "a new kind of literature," 8 specifically Holocaust literature.

I make a much different claim. What leads to her transformation is not so much the content of the works that Hanna reads but her specific approach to reading. The act of reading is one of the central themes of this novel, but what scholars have not yet noticed are the stark differences in the way people read. We see this most clearly through Michael's startled response to notes Hanna sends him while she is in prison. He specifically remarks that her comments about what she has read lead him to connect with the outside world: "often it was Hanna's note that first 
made me pay attention to the forsythia, the summer storms, or the flocks of birds" $(R, \mathrm{p} .189)$. Significant here is not just the content, but also Michael's surprised response. Reading for Hanna involves more than just a personal accumulation of facts and an individual refinement of the intellect. It is an activity that links a person with the external world, and in this case, it is Hanna, isolated within a prison, who "first" makes Michael "pay attention" to the external world. Clearly, this is a form of reading that Michael finds unusual.

Hanna's approach to reading becomes even more pronounced when we contrast it with the approach of Michael's father. Schlink brilliantly visualizes the father's form of reading through the depiction of his workplace. Lacking warmth and incapable of intimacy, Michael's father treats his children and students exactly the same: "When we children wanted to speak to our father, he gave us appointments just like his students" ( $R$, p. 140). As a scholar, the father helps people refine the operations of their intellect, but he does not know how to bridge the gap between his active mind and the external world. Michael illustrates this through his depiction of his father's study: "the windows did not open the room to the world beyond, but framed and hung the world in it like a picture. My father's study was a capsule in which books, papers, thoughts, and pipe and cigar smoke had created their own force field, different from that of the outside world" (pp. 140-41). The father's philosophical world may be noble and sublime, but it has little to no connection with the outside world beyond.

For Schlink, rather than thinking, the ability to read one's way beyond one's narcissistic self to the other would make Eichmann-like behavior less prevalent and possible. This, I contend, is what Hanna discovers while in prison and what leads to her transformation. We see this most clearly through her final interaction with Michael. Michael asks Hanna if she has spent much time thinking about what she had done. Hanna's response is very telling:

I always had the feeling that no one understood me anyway, that no one knew who I was and what made me do this or that. And you know, when no one understands you, then no one can call you to account. Not even the court could call me to account. But the dead can. They understand. They don't even have to have been there, but if they were, they understand even better. Here in prison they were with me a lot. They came every night, whether I wanted them or not. Before the trial I could still chase them away when they wanted to come. ( $R$, pp. 198-99)

Before the trial, before she could read, Hanna did not feel guilty. At that time, no one held her to account, not even the court. How could she feel guilty? She merely did her duty as a responsible and sincere employee. But while in prison, she underwent a transformation, which enabled her to access the interior lives of "the dead." And what those others told her was that she violated them, and that in violating them she violated a whole range of other people, whether they were there or not. But it is important to note that Hanna finds herself culpable at this point not because she violated an abstract moral of a philosophical system or a specific law of an international tribunal ("the court"). She feels accountable because she wronged individual people. Now that she has learned how to read her way into the inner lives of others, specifically those she wronged, those others have been able to communicate to her the reality and nature of her crime. In short, learning how to read one's way to the other enables one to feel the other's claim to existence.

To picture the faulty disposition that makes Eichmann-like behavior possible, Schlink has Michael interact with a man whom we can assume is a former executioner. During a hiatus in Hanna's trial, Michael hitchhikes to a concentration camp. One of the drivers who picks him up 
mocks Michael's self-righteous posturing about Nazi perpetrators, and in an authoritative tone imparts a necessary condition for a person to commit such a crime: "I'm not talking about orders and obedience. An executioner is not under orders. He's doing his work, he doesn't hate the people he executes, he's not taking revenge on them, he's not killing them because they're in his way or threatening him or attacking him. They're a matter of such indifference to him that he can kill them as easily as not" ( $R, \mathrm{p} .151)$. One of Eichmann's claims was that he diligently organized transports of Jews to concentration camps so efficiently because he was under orders to do so. This passage rejects that claim. No authority figure is standing over the executioner compelling obedience. The perpetrator merely does his job. The problem here is not mindless obedience to an authority; it is that executing a Jew occasions as much inner turmoil as slaughtering a cow. Since the perpetrator has no interest in the inner life of others, he does not feel accountable to them, so he can kill them with emotional impunity.

An inability to read the inner life of the other and a lack of desire to do so are of paramount importance in explaining why people like Hanna could violate others without feeling any remorse. Juxtaposing pre- and posttrial scenes of Hanna brings the distinct forms of reading into sharp focus. Before the trial, taking an active interest in the inner life of the other does not even occur to Hanna. After Michael and Hanna had been together for six or seven days, Michael, who only knows Hanna's last name, asks what her first name is. Hanna is surprised by the question, so she asks why he wants to know. Since Hanna cannot read the name on Michael's backpack, she has no idea what his name is and it does not even occur to her to ask until Michael asks her name. This pattern is repeated. Michael asks Hanna "about her life" ( $R$, p. 39), but Hanna "didn't understand why I was interested in what had happened to her parents, whether she had had brothers and sisters, how she had lived in Berlin and what she'd done in the army" (p. 39). Near the end of their relationship, Michael starts to discover that Hanna takes no interest in his inner life. After asking when her birthday was, he notes that "she hadn't asked me when mine was" (p. 73).

The problem is not just that Hanna lacks interest in others; it is that, even if she had the interest, she does not have the capacity to read their inner lives. The most obvious example of her inability to read her surroundings and others occurs during her trial. Hanna wants to be as accurate as possible in her testimony, so she corrects the record when it contains misrepresentations. But instead of helping her case, her reactions alienate, because "she did not notice that her insistence annoyed the presiding judge. She had no sense of context, of the rules of the game, of the formulas by which her statements and those of the others were toted up into guilt and innocence, conviction and acquittal" ( $R$, p. 110). Hanna could not modify her answers in relation to her audience, because she does not know how to read others.

These two failings - taking no interest in others and lacking the ability to read others - are crucial when we take into account one of the works on Hanna's bookshelf, the memoir of Rudolph Höss. As commandant of Auschwitz, Höss is considered the biggest mass murderer in history. His memoir, written while awaiting execution, documents what led him to do what he did and what occurred in Auschwitz. Like Michael's father, reading for Höss does not connect a person to the outside world. Rather, it is a narcissistic act of self-actualization. Höss makes this point when he describes being in prison as a young man. Reflecting on the fellow inmates who are in despair, Höss notes that "a good book or a serious hour of meditation compelled these characters to explore their inner selves and their consciences quietly."9 This is exactly how Höss 
reads. Here is what he says while in prison: "I buried myself in my books and magazines or read the letters sent to me by kind and dear people. I read about their plans and intentions for me after my release and chuckled about their good intentions to cheer me up and console me" (DD, p. 76). For Höss, reading is not about connecting with others or understanding them on their own terms. It is only about how others can serve him and his needs.

One passage in the memoir would seem to contradict my claim. When discussing how guards should treat prisoners, Höss explains the value of reading inmates' letters: "Whoever reads the letters of a prisoner over a long period of time and has enough knowledge of human nature will get a true picture of the inmate's state of mind" ( $D D$, p. 93). Here it seems that Höss can read his way outside of his narcissistic self and thus access the interiority of others. But actually, instead of "reading-to," which is an act of accessing the other outside of or beyond one's own preconceived notion or agenda, Höss "reads-in-order-to," which is a form of knowing in order to control and dominate. In this case, the objective is to identify "ENEMIES OF THE STATE" (p. 93). Some prisoners think that they can trick prison officials about their allegiances, but Höss says that the prisoner "cannot fool the trained eye of the experienced observer, not even in letters" (p. 93). Reading for Höss is about slotting people into categories, either the friends or the enemies of the state. Their identities independent of these political categories are meaningless.

Thus, it should come as no surprise that Höss fails to understand what victims of his atrocities must have experienced. Two passages in particular stand out. Höss claims that he became fond of gypsies when he was commandant, which is why it was heartbreaking for him when he was forced to have them exterminated. After briefly describing how the doctors separated the children from their parents, Höss remarks: "Surely nothing is more difficult than to have to go through all this, to be cold, without mercy, and without compassion" (DD, p. 138). Höss is talking about what the doctors suffered in selecting the victims. My suspicion is that it would have been infinitely more difficult for the victims to be traumatized, subjugated, maimed, and exterminated, but this is such an insignificant difficulty that Höss does not consider mentioning it. The most glaring example of Höss's obtuseness can be seen when he was imprisoned after the war. While in Poland, "several officials approached" him and "showed" him "their Auschwitz tattoo numbers." From this experience, Höss concludes: "I could not understand them, but I do not suppose they wished me well" (p. 180). It does not take geniuslevel reading ability to understand that the victims were telling Höss that he committed one of the most heartless, barbaric, degrading, demoralizing, and horrendous crimes known to humanity.

For Schlink, these two failures (desire and ability) in reading-to are precisely what enabled both the executioner and Hanna to commit their atrocities. So that this reading-to theme could become more apparent, Schlink concludes the novel with three characters who have cultivated the art of reading-to. The warden of Hanna's prison wants her inmates to reform and succeed, so she is devastated by Hanna's suicide. When she takes Michael to Hanna's cell, she asks Michael why he sent her cassettes, and she then asks: "You knew that she was illiterate, didn't you? How did you know?" ( $R$, p. 204). As a skillful reader, she rightly infers something important about Michael's relationship with Hanna, and she asks another question to get clarity and additional insight. But Michael has no interest in responding, so he merely shrugs his shoulders. 
The most skillful reader is the Jewish woman who survived the church fire. Michael visits this woman to give her money that Hanna bequeathed to her. But the woman is puzzled, so she asks Michael about the nature of his relationship with Hanna. As an excellent reader, she immediately discovers that Michael and Hanna had a sexual relationship when he was just fifteen years old, which leads her to make the following comments:

"That woman was truly brutal ... did you ever get over the fact that you were only fifteen when ... No, you said yourself that you began reading to her again when she was in prison. Did you ever get married?"

I nodded.

"And the marriage was short and unhappy, and you never married again, and the child, if there is one, is in boarding school." $(R$, p. 213)

Without knowing him, this woman has been able to read Michael with stunning precision - what she says about Michael is exactly right. What, in part, makes this possible is her ability to pose questions and engage in conversation. When Michael shares with the Jewish survivor some crucial information about his relationship with Hanna, the woman poses many follow-up questions and makes significant inferences and observations. She can clearly attend to the inner lives of others.

Given my reading of the novel, one of the most important scenes occurs when Hanna reads her way to Michael during his visit with her in prison. Hanna realizes that Michael is severely limited as soon as she sees him. Here is how Michael describes Hanna's response: "I saw the expectation in her face, saw it light up with joy when she recognized me, watched her eyes scan my face as I approached, saw them seek, inquire, then look uncertain and hurt, and saw the light go out of her face" $(R, \mathrm{p}$. 196). No warmth, no intimacy, and certainly no human connection. Now a skillful reader, Hanna realizes that all she can expect from Michael is the businesslike formality of a functionary performing his official duty, which he does by telling her that he has found her an apartment and a job and "about the cultural and social programs available in that part of the city" (p. 197). The issue here is not the failure to think, as Arendt says of Eichmann. Schlink goes out of his way to give readers in the characters of Michael's father, a philosopher, and Michael, a legal historian, figures that commit themselves to the art of thinking. The problem is a failure to read one's way to the other. ${ }^{10}$

In essence, Michael is a mechanical being. Of course, there are signs of this even before Michael visits Hanna in jail. For instance, it might seem that Michael's decision to tape books for Hanna is an incredibly thoughtful act, exhibiting warmth and kindness. But the reality is that Michael merely does what duty dictates, a totally mechanical response that requires no investment of self. As Michael says about the tapes: "I never made a personal remark on the tapes, never asked after Hanna, never told her anything about myself. I read out the title, the name of the author, and the text. When the text was finished, I waited a moment, closed the book, and pressed the Stop button" ( $R$, p. 186). As the quintessential mechanical man, Michael gives no evidence that he has an interior life and he expresses no interest in Hanna's. In making the tapes for Hanna, Michael is merely fulfilling a mechanical duty in the same way that both Hanna and the executioner did. Her inner life as well as the inner lives of victims matter not a jot. 
This mechanical response makes Michael strikingly similar to Höss. In a letter to his wife, Höss tries to explain what accounts for the central contradiction at the core of his being: "It is tragic that, although I was by nature gentle, good-natured, and very helpful, I became the greatest destroyer of human beings who carried out every order to exterminate people no matter what." Like Michael, Höss is a gentle man who would like to help others. And yet he is a destroyer of people. This, Höss explains, is the result of becoming "a blind, obedient robot who carried out every order" $(D D$, p. 189). Robots can be programmed to do a dutiful task, whereas humans can be personal and warm. The lack of interest in others and the inability to read one's way to them, failings that make individuals robotic rather than human, are what make figures like Hanna, Eichmann, the executioner, and Höss capable of violating people with impunity.

Having understood what made her, Eichmann, and Höss capable of destroying innocent people, Hanna kills herself because she discovers that Michael has become what she once was. Therefore, instead of reentering a world that has made significant progress, she realizes that, if released, she will return to a society that suffers from the same dysfunctional way of being that was pervasive during the Nazi period. Hanna figures this out immediately after she tells Michael about how she feels accountable to the dead. What Hanna says is so staggering and remarkable that significant analysis and many follow-up questions would be necessary to unpack the nature of her claims and logic. For instance, one could ask: When you say that the dead hold you to account, do you have specific people in mind? Do you know who they are? If so, how do you know them? What changed after the trial so that they would visit you nightly? When exactly did the change happen? And in what sense do they visit you? In dreams? Or do they keep you awake at night? These are just a few of the questions that Hanna's comments should have elicited. Michael, however, has a much different response; Hanna "waited to see if I had anything to say, but I couldn't think of anything" ( $R$, p. 199).

Textual evidence supports Hanna's fear about this mental orientation being pervasive. We know that Michael, despite his criticisms of his father, becomes like him. When Michael was still in school, he had a friendship with a student named Sophie. Puzzled by Michael's mysterious absences and his aloof disposition, Sophie wonders if something is bothering him. Michael replies that there is a reason, but he does not specify it. This leads Sophie to identify the two major failings (lack of desire and inability to connect) that plague Michael: "Do you not want to talk about it, or is it that you want to but don't know how?" Michael realizes that he "didn't know the answer" $(R, \mathrm{p} .76)$ to that question. The problem is that Michael "inwardly ... felt no involvement" (p. 101) with other people. And when Michael finally does make an effort to connect with others, he discovers that they are just as disinterested or incapable as he is. For instance, after finally opening up to other women about his experiences with Hanna, he realizes that "the women didn't want to hear that much" (p. 174).

Schlink brilliantly concludes the novel with a haunting symbol that best expresses the subtle but pervasive reality of the failure to read-to. After Hanna bequeaths the Jewish survivor her money, which Michael delivers personally, the woman tells Michael that she cannot accept it, so she encourages Michael to donate it to a charity of his choice. Michael selects the Jewish League Against Illiteracy. In the last lines of the novel, Michael says: "I received a short, computergenerated letter in which the Jewish League thanked Ms. Hanna Schmitz for her donation. With the letter in my pocket, I drove to the cemetery, to Hanna's grave. It was the first and only time I stood there" ( $R$, p. 218). Michael is no anomaly. His failure to read-to is a mass problem, which 
is confirmed when Hanna gets a computer-generated form letter from an organization devoted to literacy that is addressed to a deceased Nazi perpetrator thanking her for her donation. There has been some progress; the robot has become a computer. The form letter is certainly a fulfillment of an obligation, but as a computer-generated act of officialese, it perfectly symbolizes the kind of literacy expected of people in the contemporary world - a bureaucratic obligation that is inattentive to internal realities (such as being a former Nazi and dead). The contemporary world both presupposes and encourages Michael's preferred form of literacy, which fails to make connections between people and with people in the real world. In short, the contemporary world is contributing to the making of preliterate Hannas, executioners, Michaels, Hösses, and Eichmanns, which is why it makes sense to end the novel in a cemetery.

\section{II}

My claim is that Hanna, in cultivating the art of reading-to, registers the horror of what she has done. If we accept my interpretation about Hanna developing the capacity to read-to, this would explain a shift in her sense of accountability and give form and dimension to "the dead" who visit her in prison. Before learning to read-to, she did not feel accountable to "the court" $(R$, p. 198). As a robotic servant of the Reich, she only felt accountable to Nazi authorities, figures like Eichmann and Höss, who in turn felt accountable mainly to Hitler and Himmler. But having developed a desire to understand the victims and an ability to read her way to their lives, she feels accountable only to the dead, figures like Wiesel, Améry, Borowski, and Levi. Michael, I contend, could not understand the staggering ramifications of Hanna's claim about accountability, which is one reason why he asks her no follow-up questions, because he has never learned how to read-to. There is an unbridgeable divide between the two; the idea of accountability best expresses the difference. Michael thinks of accountability in terms of a moral law (philosophy) or a judicial ruling (jurisprudence), while Hanna thinks of it in terms of the victimized "dead."

Given Hanna's capacity to read-to and the books on her shelf, we can make some logical inferences about the dead who visited her. The first is Wiesel's father. One suspects that Schlink based Hanna's story in part on Wiesel's memoir. Both works are set in Auschwitz, and after Russian troops near the camp, guards force Jews to leave. For Wiesel and his father, the death march takes them to an "abandoned village," "while Hanna and her prisoners go to an "almost deserted village" ( $R, \mathrm{p} .121)$. This is where the two narratives diverge. Wiesel and his father will be relocated to Buchenwald, while all but two Jewish women under Hanna's care will lose their lives in a village church.

During the trial, when her primary allegiance was to Nazi authorities, Hanna could not understand at all what the Jewish women under her authority experienced or suffered. All that mattered to her was the faithful execution of her duty. Thus, when she is asked in court why she did not let the women out of the burning church, Hanna could only think of her responsibility in terms of the orders she had been given: "We couldn't just let them escape! We were responsible for them. . . I mean, we had guarded them the whole time, in the camp and on the march, that was the point, that we had to guard them and not let them escape" ( $R$, pp. 127-28).

But after cultivating the capacity to read-to and reading Night, I contend, Hanna would have a much different perspective of the experience. The whole narrative of Night builds toward the 
death of Wiesel's father. What would stand out for Hanna is how Wiesel understands responsibility. For pre-prison Hanna, responsibility means doing her duty. It means following the orders of authorities. But for Wiesel, responsibility is to other human beings. Note, for instance, how Wiesel, who is starving to death, struggles with this responsibility when his father is near death. Wiesel cannot find his father, so he goes looking for him. But in this moment, he has a dark thought: "Yet at the same time a thought crept into my mind: If only I didn't find him! If only I were relieved of this responsibility, I could use all my strength to fight for my own survival, to take care only of myself-Instantly, I felt ashamed, ashamed of myself, forever" ( $N$, p. 106). This sense of being accountable to another dictates Wiesel's behavior, even if it means his own death. Indeed, so strong is that sense of responsibility that the mere thought of violating it haunts the young Wiesel.

When Hanna tells Michael that she is accountable to the dead, she would have in mind people like Wiesel's father. As a guard, she marched the Jews nearly to the point of death. At that time, what the Jews felt and/or experienced would have been impossible to access or would be a matter of total indifference to her, because she had no capacity to exit her own narcissistic self or to read her emotional way to the other. But once she learned how to read-to, she would have been able to understand and even vicariously experience what Wiesel felt when his father died. This is one of the "dead" who probably visited and even haunted her while in prison, and it is one of the "dead" to whom she probably feels "accountable."

Another concentration camp narrative that foregrounds accountability to people rather than laws or authorities is Levi's Survival in Auschwitz. Throughout this work, Levi emphasizes the degree to which life in the Lager transforms people into self-serving individualists who must abandon traditional views of the "ordinary moral world" in order to "survive." 12 And yet, the work concludes with a powerful story that, if understood, would have functioned to expose and chasten Hanna beyond all measure. After the Nazis abandon Auschwitz, Levi and some of his comrades set up a habitable living space. But since they are all in the infirmary, they are afflicted with one sickness or another. A Hungarian chemist by the name of Somogyi suffers from typhus and scarlet fever. After five days of deathly silence, Somogyi speaks, telling his comrades that he has some hidden bread that they should eat because he will not survive. But the men, despite their overwhelming hunger and need for nourishment, refuse to take his reserve. For the next two days, Somogyi descends into an excruciating spiral that culminates with his death.

What makes this scene so relevant for someone like Hanna are Levi's brilliant and insightful concluding remarks. Levi notes that "it is man who kills, man who creates or suffers injustice" (SA, p. 171). This comment is followed up with an observation deriving from Somogyi's situation: "Whoever waits for his neighbour to die in order to take his piece of bread is, albeit guiltless, further from the model of thinking man than the most primitive pigmy or the most vicious sadist" (pp. 171-72). To yearn for a fellow sufferer's death in order to get food is either a barbaric or sadistic act. Why? Because "part of our existence lies in the feelings of those near to us. This is why the experience of someone who has lived for days during which man was merely a thing in the eyes of man is non-human" (p. 172). The measure of our humanity is determined by our capacity to exit our narcissistic selves and to experience the feelings of those near us. Those who fail to do this treat others as mere things, objects devoid of a human interior. Behaving in this manner makes a "person" nonhuman. Reading Survival in Auschwitz would 
have revealed to Hanna precisely why she, like Höss, is more a mindless robot than a feeling and thinking human.

While Wiesel's Night and Levi's Survival in Auschwitz are important because they give Hanna vivid images of Jewish victims, Améry's book On Suicide is most important because it offers an explanation for Hanna's suicide. Améry's goal is to examine voluntary death "from the interior of those who call themselves suicidal or suicides." 13 Améry's phenomenological approach dispenses with an absolute claim about the nature of life or suicide and foregrounds a person's specific situation. Thus, it is not possible to persuade a person that life is the highest good and therefore worth living or that suicide is a moral wrong and therefore must be rejected. For Améry, we must assess a person's specific situation from his or her phenomenological interior to determine if suicide is a suitable choice.

Central to Améry's justification of voluntary death is what he describes as a condition of échec, which is a "sense of the irreversibility of total ruin" $(O S, \mathrm{p} .41)$. This is not something that affects only an unfortunate few. According to Améry, "échec stands as a threat in the background of everyone's existence" (p. 42). And when échec strikes, voluntary death becomes not just a legitimate possibility but also an attractive option: "Wherever échec threatens constantly . . . here voluntary death becomes for everyone everywhere a promise full of potential" (pp. 42-43). Given the logic of Améry's approach, a person can maintain dignity and even heroism in and through suicide. Since humans have a natural aversion for the soul-crushing reality of échec, they can "lift themselves up in the name of their humanity and snatch death to themselves" (p. 45), an act that preserves dignity because it refuses to submit to the indignity of échec. Through this defiance, "the suicide becomes a figure just as exemplary as the hero" (p. 59).

What makes Améry's work on voluntary death so relevant and important for understanding Hanna is his focus on oppression. For Améry, suicide can be "an answer to the oppressive provocations" of life, a "resounding no to the crushing, shattering échec of existence" (OS, p. 60). When life becomes so irredeemably oppressive, rejecting it can be a noble act based on dignity and principle. It is my contention that this heroic view of voluntary death explains Hanna's suicide, but it is important to keep in mind that Hanna's vantage point is different from that of Améry. The latter was a Holocaust victim and survivor. In his book At the Mind's Limit, Améry graphically portrays his experience of being tortured by the Nazis. Torture is something from which a person can never recover, because "whoever has succumbed to torture can no longer feel at home in the world. The shame of destruction cannot be erased. Trust in the world, which already collapsed in part at the first blow, but in the end, under torture, fully, will not be regained." 14 For this reason Améry concludes: "Whoever was tortured, stays tortured. Torture is ineradicably burned into him, even when no clinically objective traces can be detected" ( $M L, \mathrm{p}$. 34). To say no through suicide to the lingering effects of Nazi atrocities is not weakness; it can be a principled and heroic rejection of a barbaric, sadistic, and unjust society.

The reading-to Hanna rejects oppression as much as Améry, but she does so as a former perpetrator. She was a person who inflicted suffering on others. Hence, her voluntary death is not a consequence of experiencing the "shattering échec of existence." It is a result of her refusal to participate again in a culture that has in place a mentality that could lead people to inflict the 
shattering échec of existence on others. If it is a choice between an oppressive society and voluntary death, then suicide is clearly the best and most noble option.

It is worth noting that Hanna's self-negating act accords with Améry's philosophy. What would be a suitable punishment for Nazi barbarism? Améry does not want people like himself to be put in the position of inflicting on perpetrators the kind of torture he experienced. Instead, he thinks that the persecutors should willingly "negate themselves and in the negation coordinate with" their victims ( $M L$, p. 69). By negation, Améry does not necessarily mean suicide. What he wants is for the perpetrator to "be swept into the truth of his atrocity," thereby leading the person to desire "to turn back time, to undo what had been done" (p. 70). My claim is that Hanna was swept into the truth of her atrocity when she learned how to read-to, when she became accountable to the victimized dead. If this is the case, then why did she commit suicide? The answer is that, now that she has unbecome (negated) what she once was, she cannot return to a society in which the mental orientation that enabled her to commit her atrocities remains operational. Hence, she commits her heroic act of self-negation, and as such, she says a "resounding no to the crushing, shattering échec of existence" as forcefully and absolutely as Améry.

Understanding that the Holocaust is more than just a pathological anomaly in civilization, that it is something that can be pervasive and enduring, is an idea that Hanna would have gotten from reading both Améry's At the Mind's Limit and Borowski's This Way for the Gas, Ladies and Gentlemen. When discussing torture, Améry says: "Torture was no invention of National Socialism. But it was its apotheosis" (ML, p. 30). What the Nazis did was not new. It was just the most extreme and intense version of oppression that occurred in civilization.

This is the central discovery one character makes in Borowski's story "Auschwitz, Our Home (A Letter)." Reflecting on what he is doing and experiencing as a prisoner in Auschwitz, the narrator, a well-educated Pole who studied art history, draws parallels between the Nazis and other world powers:

We are laying the foundation for some new, monstrous civilization. Only now do I realize what price was paid for building the ancient civilizations. The Egyptian pyramids, the temples, and Greek statues - what a hideous crime they were! How much blood must have poured on to the Roman roads, the bulwarks, and the city walls. Antiquity - the tremendous concentration camp where the slave was branded on the forehead by his master, and crucified for trying to escape! Antiquity - the conspiracy of free men against slaves! ${ }^{15}$

This dynamic has been a consistent pattern throughout history, and only now, after seeing the master/slave dynamic in its most blatant form, does the narrator realize what has been occurring since antiquity. Given the logic of this approach, "the whole world is really like the concentration camp" ( $W G$, p. 168), as one character says in the story "The January Offensive."

In essence, Améry and Borowski invite readers to think about the degree to which the mental structures and political conditions of oppression are inescapable and pervasive. Thus, when Michael visits Hanna in prison, she, having read Améry and Borowski, would have been considering the possibility that what she and the Nazis did was no mere aberration. It was simply an extreme and intensified version of what continues to occur in civilization. Therefore, when Michael visits her, she would have been attentive to the mental orientation that enabled her to 
commit atrocities with emotional and psychological impunity. What she discovers is that Michael has not yet inculcated a way of being that would rule out the possibility of Eichmannlike behavior. Indeed, he is a potential Eichmann. Rather than reentering a world in which concentration camp behavior remains possible, she commits the most defiant and noble act: suicide.

\section{III}

Schlink's major contribution in The Reader is to offer an alternative way of thinking about what made Eichmann-like behavior possible. Philosophers like Arendt fetishize thinking, suggesting that it above all else would lead to more humane behavior. Schlink rejects this view. More than anything else, what would counter (but not necessarily rule out) the mechanical indifference and robotic cruelty of people like Höss and Eichmann is the ability to read-to. Preprison Hanna, Höss, Eichmann, and the executioner lacked this ability to read-to, which explains in part their inhumanity to other humans. But Hanna is different from these three, because she learns how to read-to.

This transformation has scandalous consequences for the way we interpret Hanna's voluntary death. Just two years after publishing On Suicide, Améry took his own life. If we read his book as a suicide letter, then we should not say that his act was a sign of weakness, mental illness, or resignation. It was a heroic rejection of a twisted polity, a breathtaking denunciation of a deathbringing culture. Having learned how to read-to, Hanna, taking her cue from At the Mind's Limit, decides to negate herself after seeing that Michael has become what she once was, that the mental orientation that made her and other Nazis possible continues to operate outside the walls of her prison. This is something that Hanna cannot and will not accept. Given her rejection of that mental orientation, she, like Améry but from an obverse angle, commits the heroic act of voluntary death, thereby fulfilling Améry's "demand" that the perpetrator "negate" him or herself "and in the negation coordinate with me" (ML, p. 69).

\footnotetext{
Notes

${ }^{1}$ Crimes and Misdemeanors, dir. Woody Allen (Orion, 1989).

${ }^{2}$ See Cynthia Ozick, "The Rights of History and the Rights of the Imagination," in Obliged by Memory: Literature, Religion, Ethics, ed. Steven T. Katz and Alan Rosen (Syracuse: Syracuse University Press, 2006), pp. 3-18; and William Collins Donahue, "Illusions of Subtlety: Bernhard Schlink's Der Vorleser and the Moral Limits of Holocaust Fiction," German Life and Letters 54, no. 1 (2001): 60-81.

${ }^{3}$ Sally Johnson and Frank Finlay, “(Il)literacy and (Im)morality in Bernhard Schlink's The Reader," Written Language \& Literacy 4, no. 2 (2001): 209.

${ }^{4}$ Jeremiah P. Conway, "Compassion and Moral Condemnation: An Analysis of The Reader," Philosophy and Literature 23, no. 2 (1999): 299, 300.

${ }^{5}$ Bill Niven, "Bernhard Schlink's Der Vorleser and the Problem of Shame," Modern Language Review 98, no. 2 (2003): 395.

${ }^{6}$ Bernhard Schlink, The Reader, trans. Carol Brown Janeway (New York: Vintage International, 1998), p. 205; hereafter abbreviated $R$.
} 
${ }^{7}$ Hannah Arendt, Eichmann in Jerusalem: A Report on the Banality of Evil (New York: Penguin Books, 2006); hereafter abbreviated $E J$.

${ }^{8}$ Niven, "Bernhard Schlink's Der Vorleser," p. 393.

${ }^{9}$ Rudolph Höss, Death Dealer: The Memoirs of the SS Kommandant at Auschwitz, ed. Steven Paskuly, trans. Andrew Pollinger (New York: Da Capo Press), p. 69; hereafter abbreviated $D D$.

${ }^{10}$ For critical discussions of Schlink's decision to make Hanna illiterate, see Ozick, "The Rights of History"; Johnson and Finlay, "(Il)literacy and (Im)morality"; and John E. MacKinnon, "Crime, Compassion, and The Reader," Philosophy and Literature 27, no. 1 (2003): 1-20.

${ }^{11}$ Elie Wiesel, Night, trans. Marion Wiesel (New York: Hill and Wang, 2006), p. 87; hereafter abbreviated N.

${ }^{12}$ Primo Levi, Survival in Auschwitz, trans. Stuart Woolf (New York: Touchstone Books, 1996), p. 86; hereafter abbreviated $S A$.

13 Jean Améry, On Suicide: A Discourse on Voluntary Death, trans. John D. Barlow (Bloomington: Indiana University Press, 1999), p. xxiii; hereafter abbreviated $O S$.

${ }^{14}$ Jean Améry, At the Mind's Limits: Contemplations by a Survivor of Auschwitz and Its Realities, trans. Sidney Rosenfeld and Stella P. Rosenfeld (Bloomington: Indiana University Press, 1980), p. 40; hereafter abbreviated $M L$.

${ }^{15}$ Tadeusz Borowski, This Way for the Gas, Ladies and Gentlemen, trans. Barbara Vedder (New York: Penguin Books, 1976), p. 131; hereafter abbreviated WG. 